\title{
The Changing World Food Aid System: Some Implications of the Proliferation of Donors and Recipients
}

\author{
Edward Clay
}

\section{Dimensions of the World Food Aid system ${ }^{1}$}

In the past, food aid has been almost synonymous with the United States PL 480 programme, and therefore the greater part of the discussion of food aid, issues and problems, has been concerned with the dominant US programme and cereals, particularly wheat. However, since the late 1960s there has been a transformation of the pattern of food aid. Many of these changes are at the 'donor end' and have received as yet relatively limited attention.

First, the scale and share of the United States in total food aid has declined substantially. Total PL 480 shipments declined from a total of $17.3 \mathrm{mn}$ tons of grains and $1.1 \mathrm{mn}$ tons of other commodities in 1965 to a combined total of $3.3 \mathrm{mn}$ tons in 1974 , and have in recent years averaged less than $6 \mathrm{mn}$ tons. The US share of food aid from OECD countries has fallen from 94 per cent in 1965 to just under 50 per cent in 1980 (Table 1).

Second, the EEC through its programme of 'community action' administered by the Community Commission and the bilateral activities of the member states has come to be second only in relation to the US, accounting for 27 per cent of OECD food aid in 1980 . The increasing significance of the EEC has also brought a change in the commodity composition of food aid. In terms of the cost of food aid as reported to the DAC, EEC dairy aid currently represents approximately 11 per cent of all OECD food aid. ${ }^{2}$ The changing commodity composition of food aid has implications in changing patterns of use. The bulk of dairy products are supplied for nutrition projects and to support dairy industry development in recipient countries. The largest and most widely known of these dairy projects is Operation Flood in India which accounted for approximately 24 per cent of allocations under the 1982 EEC dairy programme.

\footnotetext{
'This paper is an expanded version of a discussion of 'Donor policy issues' in the report on the IDS Food Aid Seminar, Jan-Feb 1982 [Clay and Pryer 1982].

${ }^{2}$ Dairy products accounted for some 60 per cent of allocations for food transfers by Community Action under the aid component, Title IX, of the Community budget between 1978 and 1982 .
}

Third, there has been a simultaneous proliferation of donors institutionalised through the Food Aid Convention (see article by Parotte in this Bulletin) and contributions to the multilateral programmes, particularly WFP and IEFR. The annual cereals commitments of most donors other than the US approximates to their obligations under the FAC (Table 2). Excepting Japan, they also regularly allocate a higher proportion of their aid than the USA to multilateral channels (Table 1). The advent of the 'smaller' food aid donors potentially raises problems of programming from the viewpoint of the donor and recipient, which are developed more fully below.

Fourth, there has been a parallel growth in the number of recipient countries. The January 1982 FAO Food Aid Bulletin lists 100 recipients of cereals food aid in $1980 / 81$ and notes 'other unspecified minor shipments to several other countries and territories'. Taking account of the proliferation of donors and recipients and the increasingly wide range of project as well as programme uses of food aid, it is apparent that an enormously complex international system of transfers of largely perishable commodities has evolved over a decade. As the bulk of these transfers involve bilateral relationships between individual donors and recipients it is not surprising that the 'world food aid system' is being criticised for:

a) the complex political and economic relationships that it involves;

b) the enormous number of management and logistical problems it has created.

Fifth, the proportion of assistance going to low income countries, and in particular to sub-Saharan Africa, has increased (Table 3). This shift is in part a deliberate policy response to the perception in aid agencies and donor countries that these countries contain the bulk of the world's hungry people. Congressional amendments to US food aid legislation now require that 75 per cent of programme food aid under PL 480 Title I go to low income countries eligible for IDA credits. The implications of this shift are exemplified at the country level by Indonesia, a

Bulletin, 1983, vol 14 no 2, Institute of Development Studies, Sussex 
Food aid flows by type of transaction of OECD countries in 1980 (US\$ million)

\begin{tabular}{|c|c|c|c|c|c|}
\hline & \multicolumn{4}{|c|}{ food aid (net disbursements) } & \multirow[b]{2}{*}{$\begin{array}{r}\text { donor total } \\
\text { as percentage } \\
\text { of total food } \\
\text { aid }\end{array}$} \\
\hline & grants & loans & $\begin{array}{c}\text { contributions to } \\
\text { international } \\
\text { institutions } \\
\$ \text { million }\end{array}$ & total & \\
\hline Australia & 38.7 & 0.0 & 25.3 & 64.0 & 2.4 \\
\hline Austria & 0.0 & 0.0 & 2.6 & 2.6 & 0.1 \\
\hline Canada & 76.0 & 2.5 & 86.3 & 164.7 & 6.3 \\
\hline EEC 'national actions' & $(176.0)$ & $(0.0)$ & $(103.7)^{1}$ & $(279.7)$ & $(10.7)$ \\
\hline EEC 'Community actions' & $(275.5)^{1}$ & $(0.0)$ & $(161.4)^{1}$ & $(436.9)$ & $(16.7)^{1}$ \\
\hline EEC total & $451.5^{1}$ & 0.0 & $265.1^{1}$ & 716.6 & $27.4^{1}$ \\
\hline Finland & 0.0 & 0.0 & 4.2 & 4.2 & 0.2 \\
\hline Japan & 12.8 & 206.3 & 42.2 & $261.3^{2}$ & 10.0 \\
\hline New Zealand & 0.0 & 0.0 & 0.9 & 0.9 & 0.03 \\
\hline Norway & 0.4 & 0.0 & 21.9 & 22.3 & 0.9 \\
\hline Sweden & 7.7 & 0.0 & 39.5 & 47.2 & 1.8 \\
\hline Switzerland & 15.8 & 0.0 & 12.1 & 27.9 & 1.1 \\
\hline United States & 471.0 & 687.0 & 149.0 & $1,307.0$ & 49.9 \\
\hline Total & $1,073.9^{1}$ & 895.8 & $649.1^{1}$ & $2,618.7$ & 100.0 \\
\hline
\end{tabular}

Source: OECD Development Assistance Committee, 1981, Development Co-operation 1981 Review.

Note: ${ }^{1}$ own estimate. The multilateral contributions of individual member states as reported by the DAC include national estimates of 'contributions' to the financing of EEC Community action;

${ }^{2}$ own estimates - DAC reports $\$ 10.0 \mathrm{mn}$ of gross disbursements by Japan, in addition to the sub-totals for grant, loans and multilateral contributions.

country relatively less constrained by balance of payments problems: the US has reduced and the EEC has phased out cereals and butter oil food aid. This shift is also in part a consequence of donor emergency responses to disasters and temporary food crises which have come to be long term commitments to new refugee communities and countries without immediate prospects of a return to previously higher levels of self provision in food staples, such as Mauritania and Somalia.

However, this change of priority is also intensifying the problems of programming and utilisation of food aid commodities. The low income countries have more intractable balance of payment problems, and also frequently more serious deficiencies in management and transport, storage, distribution systems. Their total import requirements are frequently small and therefore involve relatively higher unit costs in administration and shipping [Clay and Singer 1982]. ${ }^{3}$
Many of the problems of food aid relationships, when viewed from either a donor or recipient perspective, can be seen as arising from the complexity and lack of coherence of the 'world food aid system'. From the perspective of a recipient country, the mere programming of food aid involves a sequence of annual negotiations, with potentially at least half a dozen multilateral and bilateral agencies, over a range of commodities, available under a complex set of terms and conditions relating to logistics, use and financial terms and conditions.

Broadly, the donor-end problems of programming and supplying food aid again arise from the

\footnotetext{
${ }^{3}$ The inevitability of high transport costs is indicated by the large number of recipient countries, 38 out of 100 , to which even the total supply of cereals food aid in 1980/81 was too small, less than 12,000 tonnes, to justify low cost charter shipment, ie on the assumption that all the aid was supplied in one shipment from a single source (FAO Food Aid Bulletin no 3, 1983, Table 2).
} 
Table 2

Cereals food aid: donor commitments under 1980 Food Aid Convention and actual shipments 1980/81 (000 tonnes, cereal equivalent)

\begin{tabular}{|c|c|c|c|c|}
\hline \multirow[t]{2}{*}{ donor countries } & \multicolumn{2}{|c|}{$\begin{array}{c}\text { commitments under } \\
1980 \mathrm{FAC}\end{array}$} & \multicolumn{2}{|c|}{$\begin{array}{l}\text { actual shipments } \\
\text { cereals food aid } 1980 / 81\end{array}$} \\
\hline & 000 tonnes & $\%$ of total & 000 tonnes & $\%$ of total \\
\hline Argentina & 35 & 0.5 & 50 & 0.6 \\
\hline Australia & 400 & 5.3 & 394 & 4.7 \\
\hline Austria & 20 & 0.3 & 17 & 0.2 \\
\hline Canada & 600 & 7.9 & 600 & 7.1 \\
\hline China & - & - & 25 & 0.3 \\
\hline EEC & 1,650 & 21.7 & 1,100 & 13.1 \\
\hline Finland & 20 & 0.3 & 20 & 0.2 \\
\hline India & - & - & 51 & 0.6 \\
\hline Japan & 300 & 3.9 & 567 & 6.7 \\
\hline Norway & 30 & 0.4 & 31 & 0.4 \\
\hline Saudi Arabia & - & - & 31 & 0.4 \\
\hline Spain & 20 & 0.3 & 14 & 0.2 \\
\hline Sweden & 40 & 0.5 & 91 & 1.1 \\
\hline Switzerland & 27 & 0.4 & 16 & 0.2 \\
\hline Turkey & - & - & 15 & 0.2 \\
\hline United States & 4,470 & 58.7 & 5,216 & 62.0 \\
\hline WFP purchases & - & & 13 & 0.2 \\
\hline Other & - & & 166 & 2.0 \\
\hline Total & 7,612 & 100.0 & $8,417^{*}$ & 100.0 \\
\hline
\end{tabular}

Source: i) FAO Food Aid Bulletin ne 1982

ii) Food Aid Convention 1980

Note: for 1980/81 The European Community Council decided that 928,000 tonnes should be allocated to 'Community actions', and 722,000 tonnes to 'national actions'.

This is an internal Community decision.

* Other cereals food aid under 1971 FAC was also shipped in 1980/81.

complexity of food aid relationships. Potentially each donor agency is confronted with the problems of determining the scale of assistance and allocating and supplying several commodities. Each agency has to relate its programme to multilateral activities (WFP, International Emergency Food Reserve [IEFR], International Committee for Red Cross, etc), and to a potentially very large group of recipient countries. At the same time, each agency needs to take account of the actions of other donors.

\section{Donor Roles and Perspectives:}

\section{the United States}

The implications of the halving of the level of US food transfers and the related relative reduction in the overall role of the US as a food aid donor provides a major theme of this article. The other change in the context of US policy and programming is the degree to which the scale and broad allocation of food transfers is now more heavily circumscribed by legislative provisions made in the aftermath of the Vietnam war. These modifications of Public Law 480 have been designed to give a developmental and humanitarian focus to the US food aid programme. The evolution of policy is well documented by Wallerstein [1980] and we have considered elsewhere some of the policy implications of these changes particularly for programme food aid, largely provided as highly concessional loans under PL 480 Title I [Clay and Singer 1982]. 
Cereals food aid: regional patterns of distribution 1974/75-1980/81 ${ }^{\mathrm{t}}$

\begin{tabular}{|c|c|c|c|c|c|c|c|c|c|c|c|c|c|c|}
\hline \multirow[b]{2}{*}{ region } & \multicolumn{2}{|c|}{$1974-75$} & \multicolumn{2}{|c|}{$1975-76$} & \multicolumn{2}{|c|}{$1976-77$} & \multicolumn{2}{|c|}{$1977-78$} & \multicolumn{2}{|c|}{$1978-79$} & \multicolumn{2}{|c|}{$1979-80$} & \multicolumn{2}{|c|}{$1980-81$} \\
\hline & $\begin{array}{c}000 \\
\text { tonnes }\end{array}$ & $\begin{array}{c}\% \\
\text { total }\end{array}$ & $\begin{array}{l}\text { 000 } \\
\text { tonnes }\end{array}$ & $\begin{array}{c}\% \\
\text { total }\end{array}$ & $\begin{array}{c}000 \\
\text { tonnes }\end{array}$ & $\begin{array}{c}\% \\
\text { total }\end{array}$ & $\begin{array}{l}000 \\
\text { tonnes }\end{array}$ & $\begin{array}{c}\% \\
\text { total }\end{array}$ & $\begin{array}{c}000 \\
\text { tonnes }\end{array}$ & $\begin{array}{c}\% \\
\text { total }\end{array}$ & $\begin{array}{c}000 \\
\text { tonnes }\end{array}$ & $\begin{array}{c}\% \\
\text { total }\end{array}$ & $\begin{array}{l}000 \\
\text { tonnes }\end{array}$ & $\begin{array}{c}\% \\
\text { total }\end{array}$ \\
\hline $\begin{array}{l}\text { sub-Saharan } \\
\text { Africa }\end{array}$ & 958 & 11.2 & 752 & 11.0 & 869 & 9.8 & 1325 & 14.4 & 1174 & 12.4 & 41603 & 18.0 & 2289 & 27.3 \\
\hline $\begin{array}{l}\text { West Asia and } \\
\text { North Africa }\end{array}$ & 972 & 11.4 & 1299 & 19.0 & 2669 & 30.2 & 2520 & 27.3 & 2644 & 27.8 & 2260 & 25.4 & 2272 & 27.1 \\
\hline South Asia & 4612 & 54.0 & 3351 & 49.0 & 2809 & 31.8 & 2516 & 27.3 & 2586 & 27.2 & 2339 & 26.2 & 1747 & 20.8 \\
\hline $\begin{array}{l}\text { East Asia and } \\
\text { Pacific }\end{array}$ & 910 & 10.6 & 600 & 8.8. & 1831 & 20.7 & 1971 & 21.4 & 2016 & 21.2 & 21524 & 17.1 & 1135 & 13.5 \\
\hline $\begin{array}{l}\text { Central and } \\
\text { South Americas }\end{array}$ & 596 & 7.0 & 538 & 7.9 & 243 & 2.7 & 372 & 4.0 & 605 & 6.4 & 718 & 8.1 & 564 & 6.7 \\
\hline $\begin{array}{c}\text { 'Developed' } \\
\text { Countries }\end{array}$ & 147 & 1.7 & 175 & 2.5 & 293 & 3.3 & 438 & 4.8 & 395 & 4.2 & 323 & 3.6 & 284 & 3.4 \\
\hline $\begin{array}{l}\text { Unspecified }^{2} \\
\text { destination }\end{array}$ & 348 & 4.0 & 131 & 1.9 & 126 & 1.4 & 75 & 0.8 & 80 & 0.8 & 143 & 1.6 & 105 & 1.2 \\
\hline
\end{tabular}

Total

$\begin{array}{llllllllllllll}8544 & 100.0 & 6846 & 100.0 & 8840 & 100.0 & 9217 & 100.0 & 9500 & 100.0 & 8910 & 100.0 & 8396 & 100.0\end{array}$

\section{Source: FAO Food Aid Bulletins}

Notes: ' cereals converted to wheat equivalent according to rules of Food Aid Convention. The regional groupings are approximately those of the UN Regional Commissions except that South Asia, including Afghanistan, Bangladesh, Bhutan, India, Nepal, Pakist an and Sri Lanka is defined as a separate region;

${ }^{2}$ refers mainly to cereals channelled through UN agencies for which no country breakdown is available. Includes also minor shipments to several other countries and territories.

Perhaps the most important point to note is the extent to which both 'outsiders' and many 'insiders' in the US policy process (in congress as well as the administration) have not, at least until recently, come to terms explicitly and more fully with the policy implications of having to programme food aid in a multi-donor context where the US is only primus inter pares. Ironically, the myth of US food power was given unsubtle expression originally, particularly by US Secretary of Agriculture, Earl Butz, in the early 1970s. This myth as applied to food aid, taken up by commentators on Third World policy, only too happy to attribute a large share of the difficulties of many governments out of accord with Washington to US food aid, gained credibility, ironically, at the moment of collapse of what had been for two decades a wholly US dominated world food aid system.

The notion that US food aid is a potential weapon of awful significance is no longer plausible given the changed structure of the food aid system and world food markets. At the grandest level this has been illustrated by the debacle of the Soviet grain embargo over Afghanistan. However, the scope for exerting leverage through the food weapon is limited in relation to the many recipients of food aid. Thus, the many small recipients in Africa whose imports are marginal in relation to total food aid and the programmes of most donors, have alternative sources of concessional supply. An examination of food aid flows also shows that the relative significance of any one donor varies sharply from country to country with, for example, the EEC, Australia and even Sweden, being in particular years the major source of concessional supply [Clay 1982].

Those Third World countries, such as Bangladesh and Egypt, whose normal or emergency food import requirements are non-marginal in relation to individual donor programmes or total food aid, are unable to meet a significant part of their import bill on concessional terms on any regular basis without US participation. But recent experience has underscored 


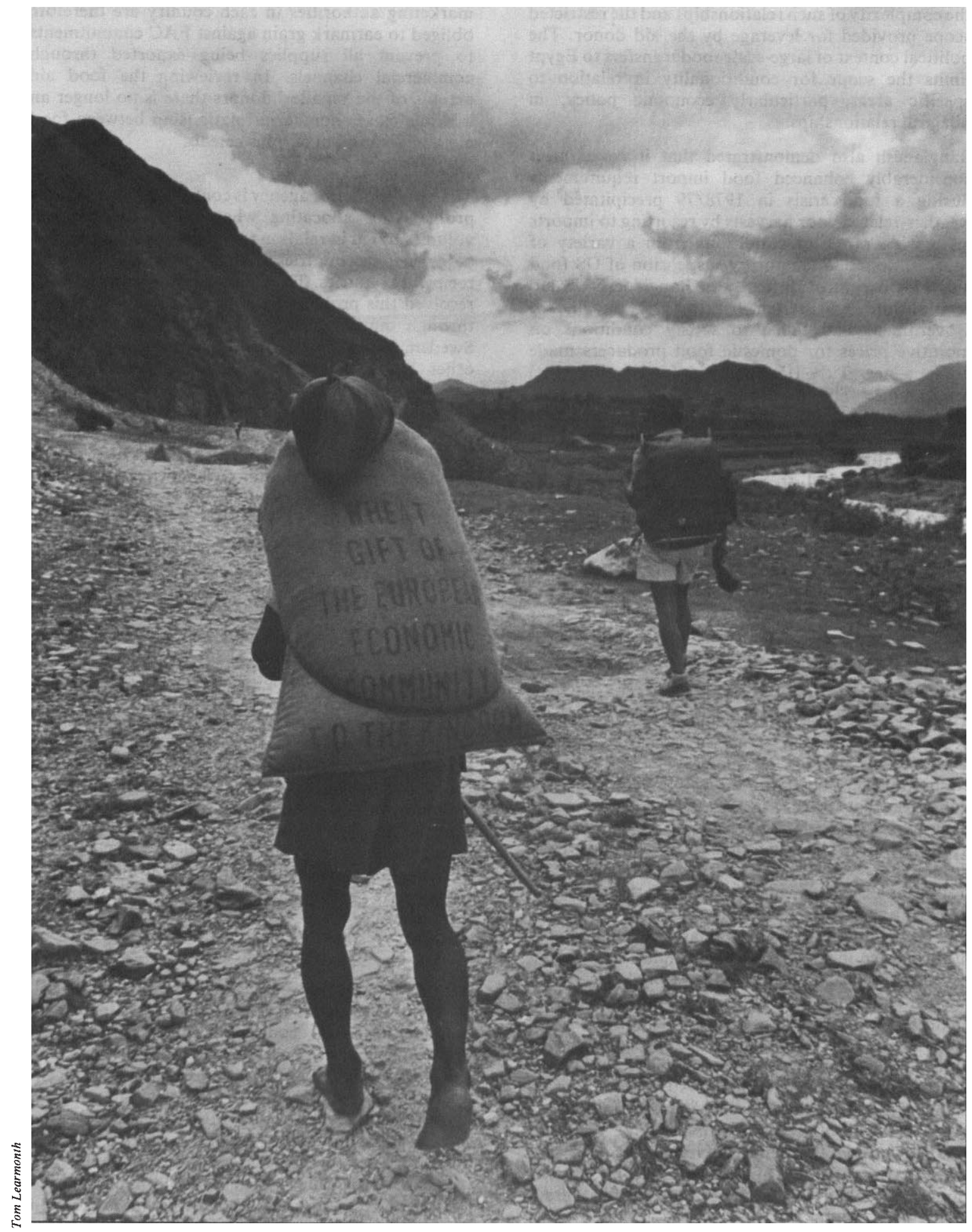

Near Pokhara, Nepal, EEC food aid is carried up to the mountains. 
the complexity of such relationships and the restricted scope provided for leverage by the aid donor. The political context of large-scale food transfers to Egypt limits the scope for conditionality in relation to specific areas, particularly economic policy, in bilateral relationships.

Bangladesh also demonstrated that it could meet considerably enhanced food import requirements during a food crisis in $1978 / 79$ precipitated by weather-related poor harvests by resorting to imports on a wide range of conditions from a variety of sources, despite a temporary suspension of US food aid. This period of difficulty in Bangladesh-US aid relationships had arisen because the Bangladesh Government had failed to satisfy conditions on incentive prices for domestic food producers made under a new Title III (food aid for development) programme. ${ }^{4}$ This food and food aid crisis placed considerable strain on the financial and managerial resources of the Bangladesh Government, but demonstrated that even a country highly dependent on food aid can find freedom of manoeuvre in its relationships with aid donors (see below). This experience is also a cautionary tale for simplistic advocates of attaching heavy agricultural price conditionality to agreements in the current round of economic adjustment and negotiations with food deficit countries.

\section{Donor Roles and Perspectives: the Other Donors}

The programmes of the other mostly smaller donors are heterogeneous in terms of scale, commodity composition, balance of bilateral and multilateral commitments. The first problem for the food aid donor is that there are no obvious criteria for determining the scale and commodity composition of a programme in terms of food import requirements of developing countries. Countries seem to have institutionalised programmes of varying size according to essentially political assessment under the FAC, taking account of national comparative advantage or disadvantage in food exporting. Similar negotiation processes have resulted in institutionalising multilateral commitments within joint donor commitments against international targets, eg FAC, IEFR, WFP etc. The essentially political nature of these decisions at the level of the individual donor is indicated by the procedures of the Canadian and Australian Governments. The total annual levels of cereal food aid are based on the negotiated commitments under the Food Aid Convention. In recent relatively tight commodity markets the availability of grain to meet commitments cannot be taken for granted. The national grain

${ }^{4} \mathrm{On}$ the 'new' Title III provisions of PL 480, see ADC [1979]. marketing authorities in each country are therefore obliged to earmark grain against FAC commitments to prevent all supplies being exported through commercial channels. In reviewing the food aid actions of the 'smaller' donors there is no longer an obvious close short-term relationship between food aid and disposal of surplus cereals.

The 'smaller' donor agency is confronted with difficult problems of allocating what are relatively small volumes of aid in relation to the import requirements of low income count ries to a large number of potential recipient countries. The Scandinavian countries have resolved this problem by allocating their aid largely through multilateral channels and, in the case of Sweden, channelling food aid, along with almost all other bilateral assistance, to a small number of countries, selected for their constructive development policies. In recent years Sweden has been one of the most important suppliers to Mozambique, indicating how even a relatively small donor can also play a significant role in relation to countries with small import requirements.

Australia and the EEC, who allocate the major part of their food aid bilaterally, find themselves confronted with difficult problems. Both have explored the use of objective statistical allocation rules. The EEC Commission has, for example, employed per capita income criteria to determine country eligibility for aid with transport costs also met by the Community. Donors would like to find more satisfactory ways of balancing needs, other aid policy objectives and cost effectiveness, but current ad hoc practice indicates a general lack of satisfaction with concepts of need or food aid requirements arrived at from juggling the per capita income, population size, state of malnutrition, scale of food deficits etc. For all the donor countries with bilateral programmes are also engaged in the difficult balancing act of rationalising their overall programme of allocations whilst taking into account the needs of specific countries and the actions of other donors.

In looking at the role of food aid in relation to the food problems of individual countries - food insecurity, malnutrition and economic adjustment faced by individual countries - there is a discernible trend towards multiannual programming, consistent packages of food aid, perhaps arrived at within a donor consortium, such as that for Mali. Yet it is clear that there is a real tension between the desire to achieve more rational, overall allocation of food aid, and moves towards tailoring all food aid allocations to circumstances of individual countries and integration with other assistance. 
The current patterns of donors' programmes reflect a balance of geographical and political considerations and an ad hoc response to what is perceived to be the food aid priority countries. EEC food aid programmes have included large allocations to a small number of densely settled low income countries - Bangladesh, Egypt, Pakistan and India (dairy products), with a large number of small allocations, virtually all going to the Lomé group of countries. Australian bilateral assistance is largely concentrated on African and Asian countries around the Indian Ocean basin. The Canadian programme in general, currently goes to high priority countries and those with very large import requirements.

\section{Multilateral Commitments}

The comparison of current procedures revealed a wide range of practices amongst donors in terms of the way they meet and domestically budget their bilateral commitments [Clay and Pryer 1982:44-5]. These commitments are institutionalised only by informal convention. Many smaller agency programmes are geared to channelling a large proportion of their FAC commitments through multilateral agencies and to do otherwise would present serious short-term administrative problems of organising alternative outlets. Multilateral programmes involving a high proportion of longer term nutritional and development projects remain highly vulnerable to changes in bilateral donor policy. This was demonstrated when the new US administration in 1981 considered abandoning the conventional practice of meeting 25 per cent of WFP requirements.

\section{Non-Cereals Food Aid Programmes}

There are no institutionalised commitments comparable to the grains Food Aid Convention. The EEC Programme has its origins in surplus disposal problems of the early 1970 s. The Community has since come close to institutionalising its dairy programme at levels of 150,000 tonnes of dried skimmed milk and 45,000 tonnes of butter oil under its 'community actions' programme without regard to year to year market conditions. The rationale for a programme of this scale, more than 10 per cent of all food aid, as a development transfer is now being called in question (see the statement by the British Foreign Secretary and Tony Jackson's recent assessments of EEC food aid in this Bulletin).

Vegetable oils have been the most important noncereals food transfer from the USA, usually in excess of 200,000 tonnes annually, in recent years. These transfers are largely bilateral highly concessional loans under PL 480 Title I. In addition, there are a range of grant transfers linked to nutritional programmes of voluntary agencies and multilateral agencies. These programmes, like so much of food aid, appear to have become institutionalised both by many years of operation and quantitative commitments of support to this complex of project and emergency aid actions under PL 480 Title II. The commodity composition of Title II has, like EEC aid, recently come under close scrutiny [National Research Council 1982].

Australia and Canada currently make annual financial allocations of non-cereals food aid, currently Australian dollars $4.14 \mathrm{mn}$ and Canadian dollars $2 \mathrm{mn}$. In the past, Canadian commitments of dairy food aid have reflected changing levels of commodity surpluses.

Many programmes include quite small quantities of processed cereal, dairy and other commodities. So far, none of the donors has attempted to establish rational allocation criteria comparable to those for cereals. Non-cereals food aid is an area which requires extensive evaluation and analysis to establish overall priorities and to identify ways of increasing programme effectiveness (see articles by Maxwell and Jackson in this Bulletin).

For references see page 61 . 